\title{
Reading psychoanalytically
}

Fernanda Negrete

Evelyne Grossman, The anguish of thought. Translated by Matthew Cripsey and Louise Burchill. Minnesota University Press, 2018.

Grossman's investigation foregrounds a shared truth encountered by a variety of wellknown, challenging critics, novelists, philosophers, and analysts of French expression in the twentieth century: thinking in its most rigorous sense is an act inevitably tied to anguish. The conjunction of "thinking," penser, with an affect whose decidedly physical signs the author details at the outset - "a knot in your stomach," "cramping of muscles," "nausea," and "curling into a ball," to name a few - is present in the book's title. In their English translation, Cripsey and Burchill deliberately choose "anguish" over the more common "anxiety" to translate angoisse, thus aptly suggesting, with Grossman, that when it comes to writers such as Artaud, Bataille, Beckett, Blanchot, Derrida, Foucault, Lacan, and Levinas, it is a question of a "literary, metaphysical anguish" (3), rather than of some "banalized, democratized anxiety [anxiété]" (3) that we more or less manage every day, often with medication and a mix of whatever we take to correspond with an ideal of balance. The notion of an unmanageable anguish that cannot answer to the usual coping methods should stand out for someone committed to psychoanalysis, as a practice that begins where the therapeutic goal of managing and lowering displeasure ends. And this ought to raise a question for someone committed to literature, which figures such as Artaud, Bataille, Beckett, and Blanchot decidedly cast as a practice that propels those committed to it beyond the pleasure principle.

The second key term in L'angoisse de penser, a verb in the infinitive ${ }^{1}$ which evidently indicates an action, "to think," becomes in the English translation a noun, "thought." This appears on the translators' part as a sudden shift in approach to the spirit of Grossman's text,

\footnotetext{
${ }^{1}$ The original title is L'angoisse de penser. If the French verb were preceded by a definite article, le (a practice common to
} French philosophy), it would be read as a noun, le penser, for which "thought" would indeed be the expected translation. 
rather than as a simple modification to preserve English idiomatic conventions, insofar as they are ready to break these in favor of allowing the specificity of the "anguish" at stake to come through for the reader. I mention this grammatical distinction between thinking as a verb and the stability of thought as a substantive because one of the most interesting ideas in Grossman's book, in my experience, concerns precisely a subjectivity in motion, a process of (un)becoming subject, due to a destabilizing experience that takes place in an act of thinking to which writing and reading are essential. But before expanding on this idea, it is worth examining the distinction between banal anxiety and the anguish Grossman qualifies as "literary." This distinction can perhaps shed light on some ways in which writing is relevant to psychoanalysis in its crucial, clinical dimension, where bodily symptoms such as those initially mentioned take on sense beyond the organism.

\section{Clinical and Literary Space}

The Anguish of Thought adopts a very fragmentary style in its discussions of texts by continental theorists and creative writers; it offers neither thorough accounts of works or concepts, nor fully fleshed-out comparisons between some of these works and figures. On Derrida, Grossman quickly mentions, for example, différance, the trace, and the relation between voice and writing that Derrida importantly critiqued, placing these alongside her reflection on the unique quality of the philosopher's speech and writing, which she draws from listening to recorded interviews she conducted with him towards the end of his life, in order to set forth the "powerless anguish" of writing and thinking (37). The book thus may seem rather odd to scholars in search of comprehensive explications of these challenging concepts. Moreover, this fragmentary approach is not subordinated to an ambition to exhaustively and systematically develop an overarching original concept, as is often the case in literary criticism, even if Grossman does put forth and consistently pinpoint the aforementioned idea of an anguish intrinsic to thinking. While this approach may be 
disconcerting, I am more interested in asking what it enables than in seeing these characteristics as flaws.

The question the book privileges across these writers is not theoretical, if by this term we understand an ideal, abstract realm detached from existence; rather, it is a matter of the core of one's being, which might, of course, also unsettle certain academic readers. Yet Grossman's analyses attest to an experience of theory as vital, thus inviting readers to call any facile distinction between theory and "real life" into question. How, then, does anguish "literary, metaphysical," but no less vital remain different from "banal anxiety"? To readers who have a commitment to psychoanalysis, but not necessarily to literature or critical theory, the distinction offers an opportunity to find in literature and criticism an ally to what makes psychoanalysis different from any psychotherapy or program aimed at eradicating any symptoms of anxiety. Clinicians who come across this book due, for example, to its involvement with Freud and French figures relevant to him (such as Pierre Janet, Jacques Lacan, or Pierre Fédida), may not immediately see the work's attention to philosophers and fiction writers external to the clinical field as essential to a distinctly psychoanalytic approach to anguish. However, I imagine the encounter with such other fields to be worth an analyst's while. This does not depend on whether or not an analyst is convinced by the fact that Lacan chose to explore "the common space between psychoanalysis and literaturewhich is to say, psychoanalysis' relationship with madness, death, the exhaustion of everything... as well as the cheerful lucidity it draws from this" (85). The exponents the book selects instantiate the practice of thinking and writing as a radical experience that confronts them with an internal heterogeneity that each one names differently (Foucault's "outside," Derrida's “impower" (impouvoir), Levinas' "seed of folly” or "Other-within-the-Self," Artaud's "chasm without words"...).

There is plausibly a link between the book's fragmentary approach to texts (which can, itself, bring to mind the nature of speech in an analysis) and the existential concern that returns throughout the work, and such a link seems to be about a direct effect of undergoing 
the experience of anguish -in writing, and, to the extent that Grossman positions herself as a close reader of texts, also in reading. In other words, the fragmentary effect of anguish is indicative of a decompletion of language, of speaking beings facing a fundamental gap in language, their shelter. To read closely, Grossman's book seems to state, is to undergo this decompletion. And upon reading closely, what may open up is a different space, where anguish, and not banal anxiety, becomes a certain mode of work. Blanchot's designation of "literary space" seems accurate, and highly relevant to thinking of what is at stake in analytic space: "Indeed, we shall privilege the term disassociation over that of deconstruction to designate this dynamic of affects, this trajectory of the forces of the drive at work in the space that Blanchot calls "literary' but which is clearly not so dissimilar from what Freud calls 'analytic' [F.N. for the latter emphasis]" (142-3).

\section{Subjectivity in Exile}

This space, at once literary and analytic, is, as Grossman stresses in the previous quote, unstill: it is inhabited by a "dynamic of affects" and "trajectory of the forces of the drive." The Anguish of Thought insistently resists a fixed space that contains emerging thoughts within it, and the correlative idea of an underlying repository that preserves its identity as subject. Through what it calls a mad or "paradoxical topology" (109), it instead underscores a process with language in writing and saying that uproots whoever engages in it. The book offers several striking examples of this. There is Levinas' exercise in thinking "otherwise than being," which provides Grossman with images of saying as a "motion of sailing on the high seas" (65) to escape the stagnation of identity (64). Beckett's uncertain temporality, which at once makes beginning to say and finishing once and for all impossible, is in this book more than an occasion to recall the oft-quoted "I must go on, I can't go on," since this anguish-ridden temporality informs the rhythm and scansion of Beckett's works, where "the words are inside the void, and the void is inside the words" (109). And there is an analysis of Blanchot's hallucinatory scene of reading in his novel Thomas the Obscure, where words on 
the book begin to move and stare back at the reader, which is key to Grossman's deciphering of anagrams scattered across the novel, and to the following, ethical understanding of reading, with which this review concludes:

It is possible, then, that with Blanchot, as with many other modern writers, reading is less a matter of an imaginary appropriation than our ability to cope with the effects of more or less violent and destructuring affects produced in us by the text. In other words, readers must be able to not resist the real transferential effects that the writing has on them; better still would be that they demonstrate a certain aptitude for disassociation-a quality required, as we know, just as much in psychoanalysts as analysands. Dissociate and associate, undo and redo: such is the movement entailed by Blanchot's writing and the reading of it. (142)

C2021 Fernanda Negrete 